\title{
Moquiniastrum polymorphum subsp floccosum extract: screening for mutagenic and antimutagenic activity
}

\author{
R.J. Oliveira' ${ }^{1,2,3}$, N. de David ${ }^{1,2}$, J.R. Pesarini ${ }^{1,3}$, T.D. Nogueira ${ }^{1,4}$, \\ C.A.L. Kassuya ${ }^{5}$, R.L.B. Strapasson ${ }^{6}$, M.E.A. Stefanello, \\ A.C.D. Monreal ${ }^{2}$, R. Matuo ${ }^{7}$ and A.C.M.B. Antoniolli-Silva ${ }^{1,3}$
}

${ }^{1}$ Centro de Estudos em Células Tronco, Terapia Celular e Genética Toxicológica, Hospital Universitário "Maria Aparecida Pedrossian", Empresa Brasileira de Serviços Hospitalares, Campo Grande, MS, Brasil ${ }^{2}$ Programa de Mestrado em Farmácia, Centro de Ciências Biológicas e da Saúde, Universidade Federal de Mato Grosso do Sul, MS, Brasil

${ }^{3}$ Programa de Pós-Graduação em Saúde e Desenvolvimento na Região Centro-Oeste, Faculdade de Medicina "Dr. Hélio Mandetta", Universidade Federal de Mato Grosso do Sul, Campo Grande, MS, Brasil ${ }^{4}$ Programa de Pós-Graduação em Ciência e Tecnologia Ambiental, Universidade Federal da Grande Dourados, Dourados, MS, Brasil ${ }^{5}$ Faculdade de Ciências da Saúde, Universidade Federal da Grande Dourados, Dourados, MS, Brasil

${ }^{6}$ Departamento de Química, Universidade Federal do Paraná, Curitiba, PR, Brasil ${ }^{7}$ Centro de Ciências Biológicas e da Saúde,

Universidade Federal de Mato Grosso do Sul, Campo Grande, MS, Brasil

Corresponding author: R.J. Oliveira

E-mail: rodrigo.oliveira@ufms.br

Genet. Mol. Res. 15 (4): gmr15048976

Received July 15, 2016

Accepted August 16, 2016

Published October 24, 20146

DOI http://dx.doi.org/10.4238/gmr15048976

Copyright (C 2016 The Authors. This is an open-access article distributed under the terms of the Creative Commons Attribution ShareAlike (CC BY-SA) 4.0 License.

ABSTRACT. Moquiniastrum polymorphum subsp floccosum (Cabrera) 
G. Sancho is used in traditional Brazilian medicine to treat inflammation and infection, which is supported by scientific data. However, only one study has been conducted on the mutagenic activity of the extract, which has important safety implications. This study evaluated the mutagenic/antimutagenic activity of $M$. polymorphum ethanolic extract (MPEE) in Allium cepa meristematic cells. Commercial $A$. cepa seeds were cultured for $120 \mathrm{~h}$. Treatments were performed for $48 \mathrm{~h}$ with MPEE (10 mg/mL), methyl methanesulfonate (MMS; 0.01 $\mathrm{mg} / \mathrm{mL}$ ), or in combination (MPEE + MMS). All of the experiments were performed in triplicate. A total of 15,000 cells per treatment were analyzed for chromosomal aberrations and the mitotic index. The results showed that MPEE was not mutagenic. In combination with MMS, MPEE decreased the number of damaged cells and the mitotic index. Interestingly, the most pronounced effect was observed post-treatment when the mitotic index also decreased, suggesting that MPEE may affect the cell cycle. MPEE exhibited antimutagenic activity, and may induce cell cycle arrest in A. cepa.

Key words: Chemoprevention; Bioantimutagenesis; Functional food; Nutraceutical; Macaúba

\section{INTRODUCTION}

The use of medicinal plants is the oldest practice in the healing arts. Many drugs were originally developed from folk medicines, and natural products have become significant sources of active ingredients for medicines (Cragg and Newman, 2013). Traditional medicine has enabled the treatment of common illnesses in approximately 60 to $80 \%$ of the world's population (Zar and Udwadia, 2013). The extraction of compounds from plants and the testing of the biological activity of those extracts and/or compounds represent the first steps toward identifying natural products, or semi-synthetic derivatives, that may provide new drugs (Cooper, 2004).

Moquiniastrum polymorphum subsp floccosum (Cabrera) G. Sancho (formerly Gochnatia polymorpha subsp floccosa) (Asteraceae), also known as Cambara, is a mediumsized tree with a wide geographical distribution. The floccosum subspecies can be found in the Brazilian states of Minas Gerais, São Paulo, Paraná, Santa Catarina, and Rio Grande do Sul (Roque, 2014). In folk medicine, the flowers, leaves, and bark are used in teas to treat inflammation and respiratory tract infections (Bueno et al., 2005).

Experimental studies have demonstrated that M. polymorphum ethanolic extracts and isolated compounds have anti-inflammatory (Moreira et al., 2000; Piornedo et al., 2011; David et al., 2014), antispasmodic (Schlemper et al., 2011), and cytotoxic effects in several tumor cell lines (Strapasson et al., 2012; Martins et al., 2015). Components of these extracts include sesquiterpene lactones, triterpenes, diterpenes, flavonoids, and coumarins (Farias et al., 1984; Bohlmann et al., 1986; Sacilotto et al., 1997; Moreira et al., 2000; Catalan et al., 2003).

This study investigated the mutagenic/antimutagenic activity of $M$. polymorphum trunk bark ethanolic extract (MPEE) in Allium cepa (Alliaceae) meristem cultures when combined with the alkylating agent, methyl methanesulfonate (MMS).

Genetics and Molecular Research 15 (4): gmr15048976 


\section{MATERIAL AND METHODS}

\section{Plant collection, identification, and extract preparation}

M. polymorphum subsp floccosum trunk barks were collected in May 2011 in Curitiba, PR, Brazil. The plant was identified by A.C. Cervi, Department of Botany, Universidade Federal do Paraná. A voucher specimen was deposited in the herbarium of the same institution under the No. 30100 . The bark was dried at $40^{\circ} \mathrm{C}$, ground, and extracted three times with $95 \%$ ethanol $(500 \mathrm{~mL}$ per $100 \mathrm{~g}$ of material) at room temperature, and the solvent was replaced every $24 \mathrm{~h}$. The solutions obtained were pooled, and the solvent was evaporated under reduced pressure (rotary evaporator; MA120, MARCONI Equipaments ${ }^{\circledR}$, Piracicaba, Brazil) to provide the crude extract, with a yield of 3\% compared with the initial dry mass.

\section{Chemicals}

DNA damage was induced by MMS (Acros Organics ${ }^{\circledR}$; catalog No. 156890050) at $0.01 \mathrm{mg} / \mathrm{mL}$.

\section{Experimental design}

Experiments were performed in triplicate, using commercial A. cepa seeds (Vidasul ${ }^{\circledR}$; lot No. 1811048) at room temperature on Petri dishes covered in filter paper and soaked with distilled water $(3 \mathrm{~mL})$. In all of the experimental protocols, seeds were grown for 24 $\mathrm{h}$ in distilled water followed by $96 \mathrm{~h}$ under treatment. For the antimutagenesis evaluation, simultaneous, pre-treatment, and post-treatment protocols were employed (Rocha et al., 2016), as presented in Figure 1. After treatment, the roots were collected and fixed in Carnoy's solution for at least $6 \mathrm{~h}$. They were then subjected to acid hydrolysis $(1 \mathrm{~N})$ and Schiff-stained for $2 \mathrm{~h}$ in the dark. Meristem regions were sectioned, and a $2 \%$ acetic carmine drop was added to the sections in order to prepare smear slides (Fedel-Miyasato et al., 2014a; Mauro et al., 2014). A total of 15,000 cells/treatment (1000 cells/slide, three replicates) were analyzed under a light microscope at 400X magnification.

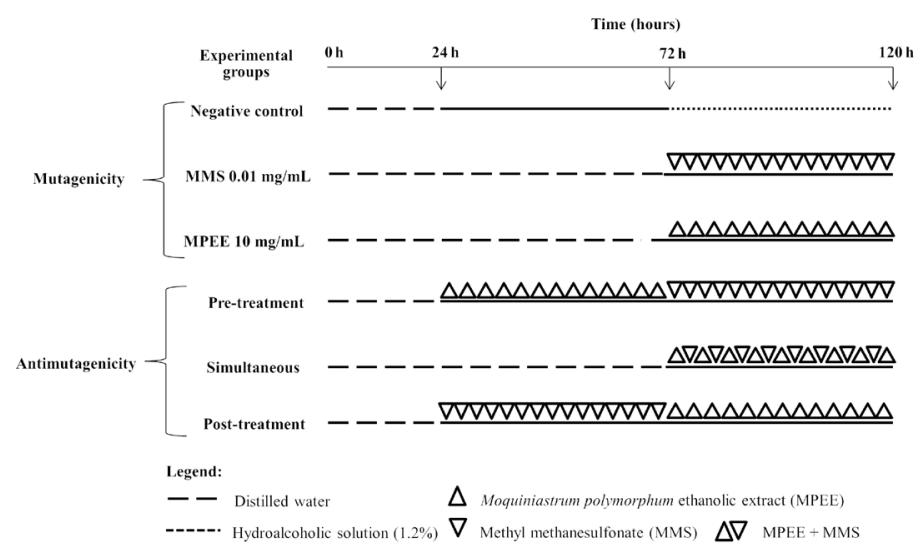

Figure 1. Experimental design for mutagenesis and antimutagenesis evaluation.

Genetics and Molecular Research 15 (4): gmr15048976 


\section{Calculating the percentage of damage reduction (\%DR)}

The \%DR was calculated using the following equation, as suggested by Manoharan and Banerjee (1985):

$$
\% \mathrm{DR}=\left[\frac{\text { Mean of positive control }- \text { Mean of associated group }}{\text { Mean of positive control - Mean of negative control }}\right] \times 100
$$

\section{RESULTS}

The results obtained from the $A$. сеpa assay revealed that MPEE was not mutagenic, and could reduce the mitotic index. When combined with MMS, the extract was capable of significantly reducing $(\mathrm{P}<0.05)$ the frequency of DNA damage in the pre-treatment, simultaneous, and post-treatment protocols, with \%DR values of $69.51,43.90$, and $99.18 \%$, respectively. The same protocols also significantly reduced $(\mathrm{P}<0.05)$ the mitotic index (Table 1; Figure 2). Regarding chromosomal and nuclear damage, micronuclei, bridges, breaks, losses, and buds were observed (Table 1).

Table 1. Chromosomal aberrations, mitotic index, and percent damage reduction.

\begin{tabular}{|c|c|c|c|c|c|c|c|c|c|}
\hline \multirow[t]{2}{*}{ Experimental group } & \multicolumn{5}{|c|}{ Chromosomal abnormality } & \multirow[t]{2}{*}{ Total } & \multirow[t]{2}{*}{ Mean \pm SEM } & \multirow[t]{2}{*}{ Mitotic index } & \multirow[t]{2}{*}{$\% \mathrm{DR}$} \\
\hline & MN & $\mathrm{BR}$ & BK & LO & $\mathrm{BU}$ & & & & \\
\hline Negative control & 5 & 2 & 2 & 1 & 0 & 10 & $3.33 \pm 1.86^{\mathrm{a}}$ & $3.87 \pm 0.29^{\mathrm{c}}$ & - \\
\hline MMS $0.01 \mathrm{mg} / \mathrm{mL}$ & 157 & 16 & 49 & 31 & 3 & 256 & $85.33 \pm 8.11^{\mathrm{c}}$ & $2.55 \pm 0.27^{\mathrm{b}}$ & - \\
\hline MPEE $10 \mathrm{mg} / \mathrm{mL}$ & 3 & 1 & 3 & 3 & 0 & 10 & $3.33 \pm 0.88^{\mathrm{a}}$ & $2.19 \pm 0.21^{\mathrm{b}}$ & - \\
\hline Pre-treatment & 47 & 10 & 17 & 9 & 2 & 85 & $28.33 \pm 3.84^{\mathrm{b}}$ & $1.74 \pm 0.16^{\mathrm{a}, \mathrm{b}}$ & 69.51 \\
\hline Simultaneous & 95 & 18 & 23 & 7 & 5 & 148 & $49.33 \pm 9.13^{b}$ & $2.40 \pm 0.19^{\mathrm{b}}$ & 43.90 \\
\hline Post-treatment & 2 & 0 & 3 & 2 & 0 & 7 & $4.00 \pm 0.58^{\mathrm{a}}$ & $0.89 \pm 0.03^{\mathrm{a}}$ & 99.18 \\
\hline
\end{tabular}

Results are reported as means \pm standard error of the mean (SEM). \%DR, percent damage reduction; MN, micronucleus; BR, bridge; BK, break; LO, loss; BU, bud; MMS, methyl methanesulfonate; MPEE, Moquiniastrum polymorphum ethanolic extract. ${ }^{\mathrm{a}, \mathrm{b}}$ Letters indicate statistically different results $(\mathrm{P}<0.05$, ANOVA/Tukey).

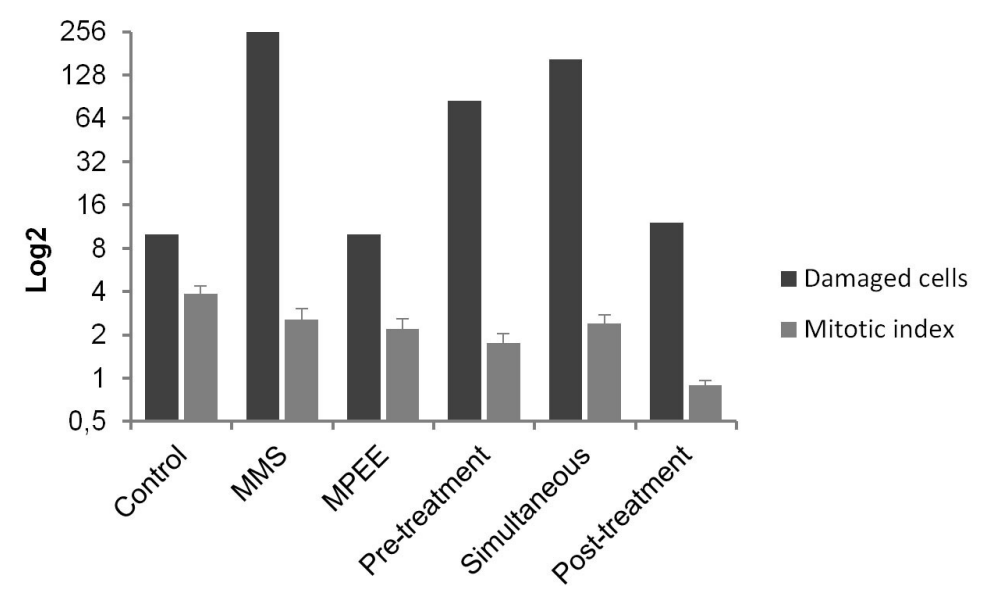

Figure 2. DNA damaged cells, mitotic index and chromossomal aberrations types in Allium cepa. Relationship between damaged cells and mitotic index among different experimental groups. MPEE: Moquiniastrum polymorphum ethanolic extract. MMS: methyl methanesulfonate.

Genetics and Molecular Research 15 (4): gmr15048976 


\section{DISCUSSION}

Plants are well-known as biological models for screening mutagens (Leme and Marin-Morales, 2009), and data obtained from plant systems exhibit 80\% agreement with data produced by mammalian model systems (Rank and Nielsen, 1997; Fedel-Miyasato et al., 2014a). An A. cepa test enables different types of analysis, such as cell cycle dysregulation, chromosomal aberrations, nuclear changes, and micronuclei formation. In addition, this assay allows clastogenic and aneugenic damage evaluation, which may provide important information regarding a compound's mechanism of action (Fiskesjö, 1993; Leme and MarinMorales, 2009). The anti-inflammatory effects of M. polymorphum are widely known (Moreira et al., 2000; Piornedo et al., 2011; David et al., 2014), and the Brazilian population consumes it as a tea to treat illnesses. However, only one study has investigated the mutagenic activity of this species (David et al., 2014).

Our results revealed that MPEE did not increase the number of cells with DNA damage ( $\mathrm{P}>0.05$ ), corroborating the findings of David et al. (2014), who observed a low frequency of micronuclei in mice treated with $M$. polymorphum. However, although the extract did not induce chromosomal aberrations, it did decrease the mitotic index, suggesting that its components may affect the cell cycle (Figure 2).

Cell division encompasses a series of well-defined and tightly regulated stages that is conventionally known as the cell cycle. Cell cycle arrest occurs if genetic material is not intact (G1/S checkpoint), and/or if problems arise during DNA replication during the $\mathrm{S}$ phase (G2/M checkpoint). This process allows cells to repair damage and subsequently continue the cycle. Another possible mechanism is the regulation of key proteins involved in cell cycle progression (Snustad and Simmons, 2013).

Sesquiterpene lactones, such as $11 \alpha \mathrm{H}$-13-dihydrozaluzanin C, 8-hydroxigochnatiolide A, 8-hydroxi-10-desoxigochnatiolide A, gochnatiolide A, gochnatiolide B, and 10-desoxygochnatiolide A, are considered the bioactive components of MPEE (Piornedo et al., 2011; Strapasson et al., 2012; Martins et al., 2015). Sesquiterpene lactones may interfere with some key biological processes, such as cell signaling, proliferation, and death/apoptosis, and mitochondrial respiration, all of which constitute the molecular basis of their diverse pharmacological activities. Dehydroleucodine (DHL) is very similar to MPEE bioactive guainolides, which are known to affect the cell cycle by inducing $\mathrm{G} 2 / \mathrm{M}$ arrest in meristematic cells of A. cepa. Cells treated with DHL exhibit interphase lengthening at $8.2 \mathrm{~h}$, probably by regulating the expression of genes involved in G2 progression, because when the cycle is restored, the cells do not exhibit any damage (López et al., 2002). The MPEE-induced decreased mitotic index may be related to cell cycle arrest that involves a similar mechanism as DHL.

Alkylating agents, such as MMS, cause DNA damage at all stages of the cell cycle, which includes base mispairing and replication blocks (Rang et al., 2012). Therefore, it was expected that MMS treatment would be associated with a decreased number of dividing cells due to increased DNA damage frequency and subsequent cell cycle arrest. This phenomenon could explain the data obtained in this study. However, if DNA damage is too extensive to be repaired, signals for cell death by apoptosis become activated. If the cell cycle progresses despite these signals, secondary damage, such as chromosomal breaks, losses, and bridges, can occur during mitosis, and nuclear budding and micronuclei formation can occur after the cell cycle has been completed.

Genetics and Molecular Research 15 (4): gmr15048976 
All of the protocols for the antimutagenesis evaluation had fewer cells with DNA damage than did the positive control. Pre- and post-treatment with MPEE substantially decreased the mitotic index, which may have been related to the cell cycle arrest that was induced by the extract. Chromosomal aberrations were detected during mitosis (chromosomal breaks, losses, and bridges) and at the end of the cell cycle (budding and micronuclei). During pre-treatment, a subset of cells returned to the cell cycle progression after $48 \mathrm{~h}$ of MPEE treatment, allowing the chromosomal damage to be observed. However, a proportion of the cells in cell cycle arrest were subject to the effects of MMS, causing cumulative damage that led to cell death. These two events may explain why less cell damage was observed with the pre-treatment protocol than with the other protocols.

In the post-treatment protocol, MMS-induced damage during the first $48 \mathrm{~h}$, after the treatment change, the cells could undergo cell cycle arrest as a result of the extract and/or extensive damage, which could lead to cell death. This hypothesis may explain why the posttreatment protocol had the lowest mitotic index (0.89). In the simultaneous treatment, the number of damaged cells was higher than in the pre- and post-treatment protocols, and the mitotic index was similar to that in the positive control. Extract compounds may chemically interact with MMS and inactivate it.

Another point that drew our attention was the antimutagenic potential of MPEE, which had a $\% \mathrm{DR}$ value of above $40 \%$ in all protocols. The main protocols in studies of antimutagenic modes of action are pre-treatment and simultaneous treatment, which indicate both desmutagenesis and bioantimutagenesis activity; simultaneous treatment with preincubation, which indicates desmutagenesis activity; and post-treatment, which indicates bioantimutagenesis activity (Oliveira et al., 2006, 2007). These protocols are frequently used in pre-clinical experiments (Fedel-Miyasato et al., 2014a,b; Cantero et al., 2015; Navarro et al., 2015; Oliveira et al., 2015; Magosso et al., 2016; Martello et al., 2016; Rocha et al., 2016; Schneider et al., 2016), and have been further adapted for the A. cepa assay (Fedel-Miyasato et al., 2014a; Felicidade et al., 2014a,b; Mauro et al., 2014; Nantes et al., 2014).

According to the data obtained, MPEE can act by desmutagenesis, but preferably by bioantimutagenesis, a hypothesis confirmed by the post-treatment \%DR value (99.18\%). It was also observed that this protocol had the lowest mitotic index, assuming that cell cycle arrest is an important event for DNA repair; immediately after repair, the cells may continue the process of division. Cell cycle arrest also contributed to the high \%DR values in the pretreatment and simultaneous protocols $(69.51 \%$ and $43.90 \%$, respectively). The pre-treatment protocol was more effective, because the meristematic cells were exposed to MPEE before MMS, and apart from desmutagenesis, MPEE can also modulate DNA-repair enzymes, and repair damage immediately after MMS exposure. Therefore, it should be expected that the pre-treatment protocol had a higher $\%$ DR value than the simultaneous protocol. Similar results were obtained by Oliveira et al. $(2006,2007)$.

The chemopreventive potential, as well as the cell cycle arrest capacity, of $M$. polymorpha supports the results of Strapasson et al. (2012), who reported anticarcinogenic activity in cultured tumor cells. In addition, Martins et al. (2015) reported that Walker-256 tumor growth was inhibited when rats were treated with a dichloromethane fraction of $M$. polymorpha. In summary, MPEE is not mutagenic, has antimutagenic potential (preferably by bioantimutagenesis), and is able to reduce the mitotic index, resulting in cell cycle arrest. These data suggest that the extract has the potential for prospecting compounds for cancer prevention and treatment.

Genetics and Molecular Research 15 (4): gmr15048976 


\section{Conflicts of interest}

The authors declare no conflicts of interest.

\section{ACKNOWLEDGMENTS}

Research supported by FUNDECT (Fundação de Apoio ao Desenvolvimento do Ensino, Ciência e Tecnologia do Estado de Mato Grosso do Sul), CAPES (Coordenação de Aperfeiçoamento de Pessoal de Nível Superior), and CNPq (Conselho Nacional de Desenvolvimento Científico e Tecnológico).

\section{REFERENCES}

Bohlmann F, Zdero C, Schmeda-Hirschmann G, Jakupovic J, et al. (1986). Dimeric guainolides and other constituents from Gochnatia species. Phytochemistry 44: 1175-1178. http://dx.doi.org/10.1016/S0031-9422(00)81575-7

Bueno NR, Castilho RO, Costa RB, Pott A, et al. (2005). Medicinal plants used by the Kaiowá and Guarani indigenous populations in the Caarapó reserve, Mato Grosso do Sul, Brazil. Acta Bot. Bras. 19: 39-44. http://dx.doi.org/10.1590/ $\underline{\mathrm{S} 0102-33062005000100005}$

Cantero WB, Takahachi NA, Mauro MO, Pesarini JR, et al. (2015). Genomic lesions and colorectal carcinogenesis: the effects of protein-calorie restriction and inulin supplementation on deficiency statuses. Genet. Mol. Res. 14: 24222435. http://dx.doi.org/10.4238/2015.March.27.27

Catalan CAN, Vega MI, Lopez ME, Cuenca M del R, et al. (2003). Coumarins and a kaurane from Gochnatia polymorpha ssp. Polymorpha from Paraguay. Biochem. Syst. Ecol. 31: 417-422. http://dx.doi.org/10.1016/S0305-1978(02)00163-1

Cooper EL (2004). Drug discovery, CAM and natural products. Evid. Based Complement. Alternat. Med. 1: 215-217. http://dx.doi.org/10.1093/ecam/neh032

Cragg GM and Newman DJ (2013). Natural products: a continuing source of novel drug leads. Biochim. Biophys. Acta 1830: 3670-3695. http://dx.doi.org/10.1016/j.bbagen.2013.02.008

David Nd, Mauro MdeO, Gonçalves CA, Pesarini JR, et al. (2014). Gochnatia polymorpha ssp. floccosa: bioprospecting of an anti-inflammatory phytotherapy for use during pregnancy. J. Ethnopharmacol. 154: 370-379. http://dx.doi. org/10.1016/j.jep.2014.04.005

Farias ACM, Da Silva JR and Tomassini TCB (1984). Constituents of Mochinea polymorpha. J. Nat. Prod. 47: 363-364. http://dx.doi.org/10.1021/np50032a021

Fedel-Miyasato LES, Formagio ASN, Auharek SA, Kassuya CAL, et al. (2014a). Antigenotoxic and antimutagenic effects of Schinus terebinthifolius Raddi in Allium cepa and Swiss mice: a comparative study. Genet. Mol. Res. 13: 34113425. http://dx.doi.org/10.4238/2014.April.30.2

Fedel-Miyasato LES, Kassuya CAL, Auharek SA, Formagio ASN, et al. (2014b). Evaluation of anti-inflammatory, immunomodulatory, chemopreventive and wound healing potentials from Schinus terebinthifolius methanolic extract. Braz. J. Pharmacog. 24: 565-575.

Felicidade I, Lima JD, Pesarini JR, Monreal ACD, et al. (2014a). Mutagenic and antimutagenic effects of aqueous extract of rosemary (Rosmarinus officinalis L.) on meristematic cells of Allium cepa. Genet. Mol. Res. 13: 9986-9996. http:// dx.doi.org/10.4238/2014.November.28.3

Felicidade I, Lima JD, Pesarini JR, Monreal ACD, et al. (2014b). Mutagenic and antimutagenic effects of crude hydroalcoholic extract of rosemary (Rosmarinus officinalis L.) on cultured meristematic cells Allium cepa. VRI Phytomedicine 2: 30-39.

Fiskesjö G (1993). The Allium test in wastewater monitoring. Environ. Toxicol. 8: 291-298.

Leme DM and Marin-Morales MA (2009). Allium cepa test in environmental monitoring: a review on its application. Mutat. Res. 682: 71-81. http://dx.doi.org/10.1016/j.mrrev.2009.06.002

López ME, Giordano OS and López LA (2002). Sesquiterpene lactone dehydroleucodine selectively induces transient arrest in G2 in Allium cepa root meristematic cells. Protoplasma 219: 82-88. http://dx.doi.org/10.1007/s007090200008

Magosso MF, Carvalho PC, Shneider BU, Pessatto LR, et al. (2016). Acrocomia aculeata prevents toxicogenetic damage caused by the antitumor agent cyclophosphamide. Genet. Mol. Res. 15: http://dx.doi.org/10.4238/gmr.15027816.

Manoharan K and Banerjee MR (1985). beta-Carotene reduces sister chromatid exchanges induced by chemical

Genetics and Molecular Research 15 (4): gmr15048976 
carcinogens in mouse mammary cells in organ culture. Cell Biol. Int. Rep. 9: 783-789. http://dx.doi.org/10.1016/03091651(85)90096-7

Martello MD, David N, Matuo R, Carvalho PC, et al. (2016). Campomanesia adamantium extract induces DNA damage, apoptosis, and affects cyclophosphamide metabolism. Genet. Mol. Res. 15: http://dx.doi.org/10.4238/gmr.15027678.

Martins GG, Lívero FA, Stolf AM, Kopruszinski CM, et al. (2015). Sesquiterpene lactones of Moquiniastrum polymorphum subsp. floccosum have antineoplastic effects in Walker-256 tumor-bearing rats. Chem. Biol. Interact. 228: 46-56. http://dx.doi.org/10.1016/j.cbi.2015.01.018

Mauro MO, Pesarini JR, Marin-Morales MA, Monreal MT, et al. (2014). Evaluation of the antimutagenic activity and mode of action of the fructooligosaccharide inulin in the meristematic cells of Allium cepa culture. Genet. Mol. Res. 13: 4808-4819. http://dx.doi.org/10.4238/2014.February.14.14

Moreira AS, Spitzer V, Schapoval EE and Schenkel EP (2000). Antiinflammatory activity of extracts and fractions from the leaves of Gochnatia polymorpha. Phytother. Res. 14: 638-640. http://dx.doi.org/10.1002/10991573(200012)14:8<638::AID-PTR681>3.0.CO;2-Q

Nantes CI, Pesarini JR, Mauro MO, Monreal ACD, et al. (2014). Evaluation of the antimutagenic activity and mode of action of carrageenan fiber in cultured meristematic cells of Allium cepa. Genet. Mol. Res. 13: 9523-9532. http:// dx.doi.org/10.4238/2014.November.12.1

Navarro SD, Mauro MO, Pesarini JR, Ogo FM, et al. (2015). Resistant starch: a functional food that prevents DNA damage and chemical carcinogenesis. Genet. Mol. Res. 14: 1679-1691. http://dx.doi.org/10.4238/2015.March.6.14

Oliveira RJ, Ribeiro LR, da Silva A, Matuo R, et al. (2006). Evaluation of antimutagenic activity and mechanisms of action of $\beta$-glucan from barley, in CHO-k1 and HTC cell lines using the micronucleus test. Toxicol. In Vitro 20: 1225-1233.

Oliveira RJ, Matuo R, da Silva AF, Matiazi HJ, et al. (2007). Protective effect of $\beta$-glucan extracted from Saccharomyces cerevisiae, against DNA damage and cytotoxicity in wild-type (k1) and repair-deficient (xrs5) CHO cells. Toxicol. In Vitro 21: 41-52. http://dx.doi.org/10.1016/j.tiv.2006.07.018

Oliveira RJ, Fronza LS, Honda RE, Aquino MT, et al. (2015). Effects of Avena sativa L. supplementation on ponderal development, reproductive performance and embryo-fetal development of pregnant rats exposed to cyclophosphamide. PECIBES 1: 1-8.

Piornedo R dos R, de Souza P, Stefanello MÉ, Strapasson RL, et al. (2011). Anti-inflammatory activity of extracts and 11,13-dihydrozaluzanin C from Gochnatia polymorpha ssp. floccosa trunk bark in mice. J. Ethnopharmacol. 133: 1077-1084.

Rang HP, Dale MM, Ritter JM, Flower RJ, et al. (2012). Rang \& Dale’s pharmacology. 7th edn. Churchill Livingstone, Edinburgh.

Rank J and Nielsen MH (1997). Allium cepa anaphase-telophase root tip chromosome aberration assay on N-methyl-Nnitrosourea, maleic hydrazide, sodium azide, and ethyl methanesulfonate. Mutat. Res. 390: 121-127. http://dx.doi. org/10.1016/S0165-1218(97)00008-6

Rocha RS, Kassuya CAL, Formagio AS, Mauro M de O, et al. (2016). Analysis of the anti-inflammatory and chemopreventive potential and description of the antimutagenic mode of action of the Annona crassiflora methanolic extract. Pharm. Biol. 54: 35-47. http://dx.doi.org/10.3109/13880209.2015.1014567

Roque N (2014). Moquiniastrum. Lista de espécies da flora do Brasil. Jardim Botânico do Rio de Janeiro. Available at [http://floradobrasil.jbrj.gov.br/jabot/floradobrasil/FB130872]. Accessed June 28, 2016.

Sacilotto ACB, Vichnewski W and Herz W (1997). Ent-kaurene diterpenes from Gochnatia polymorpha var. polymorpha. Phytochemistry 44: 659-661. http://dx.doi.org/10.1016/S0031-9422(96)00601-2

Schlemper V, Freitas SA and Schlemper SEM (2011). Antispasmodic effects of hydroalcoholic extract from Gochnatia polymorpha ssp. floccosa in the guinea pig ileum. Res. J. Med. Plant 5: 288-294. http://dx.doi.org/10.3923/ rjmp.2011.288.294

Schneider BUC, Meza A, Beatriz A, Pesarini JR, et al. (2016). Cardanol: toxicogenetic assessment and its effects when combined with cyclophosphamide. Genet. Mol. Biol. 39: 279-289. http://dx.doi.org/10.1590/1678-4685GMB-2015-0170

Snustad P and Simmons MJ (2013). Fundamentos de genética. 6th edn. Guanabara Koogan, Rio de Janeiro.

Strapasson RL, Cervi AC, Carvalho JE, Ruiz AL, et al. (2012). Bioactivity-guided isolation of cytotoxic sesquiterpene lactones of Gochnatia polymorpha ssp. floccosa. Phytother. Res. 26: 1053-1056. http://dx.doi.org/10.1002/ptr.3693

Zar HJ and Udwadia ZF (2013). Advances in tuberculosis 2011-2012. Thorax 68: 283-287. http://dx.doi.org/10.1136/ thoraxjnl-2012-203127

Genetics and Molecular Research 15 (4): gmr15048976 